\title{
Rivers Try Harder. Reversed "Differential Erosion" as Geological Control of Flood in the Large Fluvial Systems in Poland
}

\author{
Jan Stefan Bihałowicz ${ }^{1,2}$ and Grzegorz Wierzbicki ${ }^{1, *}$ \\ 1 Faculty of Civil and Environmental Engineering, Warsaw University of Life Sciences SGGW-WULS, \\ ul. Nowoursynowska 166, 02-787 Warsaw, Poland; jbihalowicz@sgsp.edu.pl \\ 2 The Main School of Fire Service, ul. Słowackiego 52/54, 01-629 Warsaw, Poland \\ * Correspondence: grzegorz_wierzbicki@sggw.edu.pl; Tel.: +48-22-59-35-237
}

Citation: Bihałowicz, J.S.; Wierzbicki, G. Rivers Try Harder. Reversed "Differential Erosion" as Geological Control of Flood in the Large Fluvial Systems in Poland. Water 2021, 13, 424. https://doi.org/10.3390/ w13040424

Academic Editor: Salvatore Ivo Giano Received: 18 December 2020

Accepted: 2 February 2021

Published: 5 February 2021

Publisher's Note: MDPI stays neutral with regard to jurisdictional claims in published maps and institutional affiliations.

Copyright: (c) 2021 by the authors. Licensee MDPI, Basel, Switzerland. This article is an open access article distributed under the terms and conditions of the Creative Commons Attribution (CC BY) license (https:// creativecommons.org/licenses/by/ $4.0 /)$.

\begin{abstract}
We study cross-sections on the Detailed Geological Map of Poland (SMGP) to find a geologic and geomorphic pattern under river valleys in Poland. The pattern was found in 20 reaches of the largest Polish rivers (Odra, Warta, Vistula, Narew, and Bug) located in the European Lowland, in the landscape of old (Pleistocene, Saalian) glacial high plains extending between the Last Glacial Maximum (LGM) moraines on the North and the Upland on the South. The Upland was slightly folded and up-faulted during Alpine orogeny together with the thrust of Carpathian nappes and the uplift of Tatra Mts. and Sudetes. The found pattern is an alluvial river with broad Holocene floodplain and the channel developed atop the protrusion of bedrock (Jurassic, Cretaceous limestones, marlstones, sandstones) or non-alluvial, cohesive, overconsolidated sediments resistant to erosion (glacial tills, lacustrine or "ice-dammed lake" clays) of Cenozoic (Paleogene, Neogene, QuaternaryElsterian). We regard the sub-alluvial protrusion as the limit of river incision and scour. It cannot be determined why the river flows atop these protrusions, in opposition to "differential erosion", a geomorphology principle. We assume it is evidence of geological flood control. We propose an environmental and geomorphological framework for the hydrotechnical design of instream river training.
\end{abstract}

Keywords: flood control; scour; incision control; alluvial substrate; rock resistance; planation surface; glaciotectonic

\section{Introduction}

Riverine floodplains cover ca. 1\% of Earth's terrestrial surface, but are among the most distinctive landscape features on the globe, as well as the most biologically productive and diverse ecosystems on our planet [1]. Due to the great fertility of floodplains, people have reclaimed most of their surface. They had great cultural and economic importance for early civilizations, but floodplains became one of the most endangered landscapes on Earth [1]. Human pression on floodplains threatens them, and it resulted in the development of a false perspective-an overestimation of the role of human efforts to control the dynamics of the alluvial plains in the river valley, especially a proximal zone of these plains.

The proximal part of a floodplain [2] is a zone adjacent to the river channel, shaped by the deposition and erosion coming directly from the main channel. Sometimes such a zone raises above the flood basin level, and is called an alluvial ridge [3]. In fluvial sedimentology, the proximal zone of floodplain represents the following facies: channel-fill, channel-belt, natural levee, and crevasse-splay [4].

From the perspective of geomorphology, the floodplain is a landform developed by fluvial deposition (geological and geomorphological definitions compiled by [5]) for a long time, thus it can be regarded as a reflection of some tendencies in the river's behavior. From the point of view of geology, the reflection of the river's behavior (mentioned above) 
lasts at least since the beginning of the Holocene [6,7], thus, much longer than the Anthropocene perspective [8-10]. Considering the fact that flood events occurred thousands of times during the Holocene, a repetition of fluvial processes in a given river reach could develop there a repetitive pattern of geological setting. The reading of such a pattern can be regarded as an attempt to understand the impact of the flood on the geological structure of the river valley as well as the geological flood control.

The results of previously published studies on this topic in a relatively small area (representing two large rivers in Poland [11-18]) indicate the existence of a specific geological pattern under the rivers flowing through the lowland landscape: the river prefers somehow to flow atop the bedrock protrusion.

The basic geomorphological principle of "differential erosion" [19-25] says something different than the paragraph above. This principle was a milestone in the conception of drainage pattern development, especially in mountainous areas of the Earth, e.g., in the Outer Carpathian Mts (OC) - the headwater of the largest river in our study. This mountain range is built on flysch-a sequence of sandstones resistant to erosion and shales susceptible to erosion. Initially, when the Carpathians were assumed as an area which underwent long-lasting tectonic quiescence after the end of alpine orogeny, differential erosion used to be perceived as a dominating process. On the presumed conditions, the Carpathian streams incised into a surface built on "soft" shales, therefore differential erosion exhumed sandstones outcrops. The sandstones formed the summit, and the walls of the OC mountain ridges. Planation surfaces of different age (from Miocene up to early Pleistocene) were described as a distinct feature of the OC geomorphology [26], but later the existence of these landforms was critically revised [27]. The revision induced doubts in the topic of differential erosion in the OC. According to the present-day views on the OC morphogenesis [28], the differential erosion still plays the most significant role on mountains exhumation, however, the eroded surface does not differ due to diversity in lithology (bedrock relative resistance [26]), but rather due to tectonics [28]. Accretionary wedges and other structures which developed between nappes are more susceptible to erosion than the structures less impacted by tectonic fragmentation [28].

In general, lowlands are perceived as an area shaped by (fluvial) deposition rather than (differential) erosion, eg., the Lower Mississippi River [4,7]. This can be a reason for the lack of papers describing the differential erosion process in the lowlands. Erosional processes in lowland rivers usually act in Holocene in alluvial deposits $[2,29,30]$. If the lowland was glaciated in Pleistocene by several advances of ice sheets, rivers had to cut through the glacial moraines [18], especially in the case of rivers flowing to the Baltic Sea in Germany, Poland, Lithuania, Latvia, and Northwest Russia, where ice sheets advanced upslope, in contrast to the Interior Plains of Northern America [7,31-34].

Such a regional framework can develop a unique relation between the geological control of flood and the evolution of the fluvial system in Holocene. The relation is written in the geological pattern mentioned above [11-18]. This specific pattern looks opposite to: (i) the pattern expected from the differential erosion, and (ii) the pattern found in a typical lowland river valley where fluvial deposition increases downstream. The increasing rate of deposition creates in the lower reach of lowland river so-called "Holocene alluvial wedge" between the bedrock (or just non-alluvial substrate of the alluvium) and the floodplain surface [4].

The existence of the specific pattern [11-18] should be verified in a larger area than the Vistula and Bug River valleys [11-18]. This is the main goal of our study: to determine the repetitive pattern of geological setting under large rivers (in the whole of Poland).

\section{Study Area, Materials and Methods}

The study area is Poland (Figure 1). The study area cannot be extended to a larger territory (e.g., continental or global scale), since we aim to use a comparative method and comparative materials-Detailed Geological Map of Poland (sometimes in English: DMGP, in Polish: SMGP, further in the text: The Map) at a scale of 1:50,000. The Map 
covers all territory of Poland by 1069 sheets (Figure 1) in a grid of the Polish Topographical Map according to the Coordinate system 1942 (EPSG: 3333, 3334 and 3335; the local implementation of Pulkovo 1942 coordinate system). All the sheets were elaborated by geologists and geomorphologists using the same, uniform instruction which is unique case in Europe and probably worldwide [35]. Each sheet of The Map contains a geological crosssection at a vertical scale of 1:2000. Our study focuses on these geological cross-sections. We review all the published sheets of The Map in order to find on the geological crosssections a repetitive pattern of geological setting under large, alluvial valleys. Such valleys exist in Middle and Northern Poland, but they dominate the landscape belt located between mountains and uplands in the south of Poland and The Lakeland (bright green and yellow) in the north of the country (colors according to Figure 1). Due to the dominance of large river valleys, this region was named The Belt of Great Valleys [36].

After a preliminary review of all published sheets (ca. 1\% of 1069 sheets is unpublished yet) of The Map, the 20 of these sheets revealed the geological cross-section presenting the discussed pattern [11-18]. The pattern is known from previous studies which were based mainly on fieldwork [11-18]. These 20 cross-sections were split into 6 groups. Each group consists of the cross-sections through the same river (or the same reach as in the case of the Vistula River, the longest and largest one). In every group, we juxtapose the different cross-sections one on each other and it was done in order to locate the river channel at the same place and to follow the same orientation consistent with the general river flow direction in Poland, namely: SW on the left river bank and NE on the right river bank. We copy from the cross-sections (published below The Map) the following lines: (i) wetted perimeter of the river channel during a medium (lower than a bankfull) stage; (ii) surface topography of the floodplain, upper terraces and the valley edges (valley walls); (iii) the bottom of Holocene alluvial sediments which can be regarded as floodplain defined by [37]; (iv) bedrock in the extent of their protrusion under the river valley. As the bedrock, we regard not only the Mesozoic solid rocks (limestones, sandstones) but also glacial tills and lacustrine (or ice-dammed lake) cohesive sediments (mostly clays) deposited during the Cenozoic, but before the Holocene. These sediments are resistant to erosion (in comparison to the Holocene alluvial sand) due to their cohesive strength [38,39] and due to strength received from glacial pressure-preconsolidation [40-42]. The lines of the upper limit of the non-alluvial protrusion were marked by a color that refers to the age according to the chronostratigraphic chart [43].

We used QGIS 3.10 [44] to draw a location map (Figure 1) and Inkscape 1.0.1 [45] to draw the 6 sets of cross-sections (Figures 2-7). 

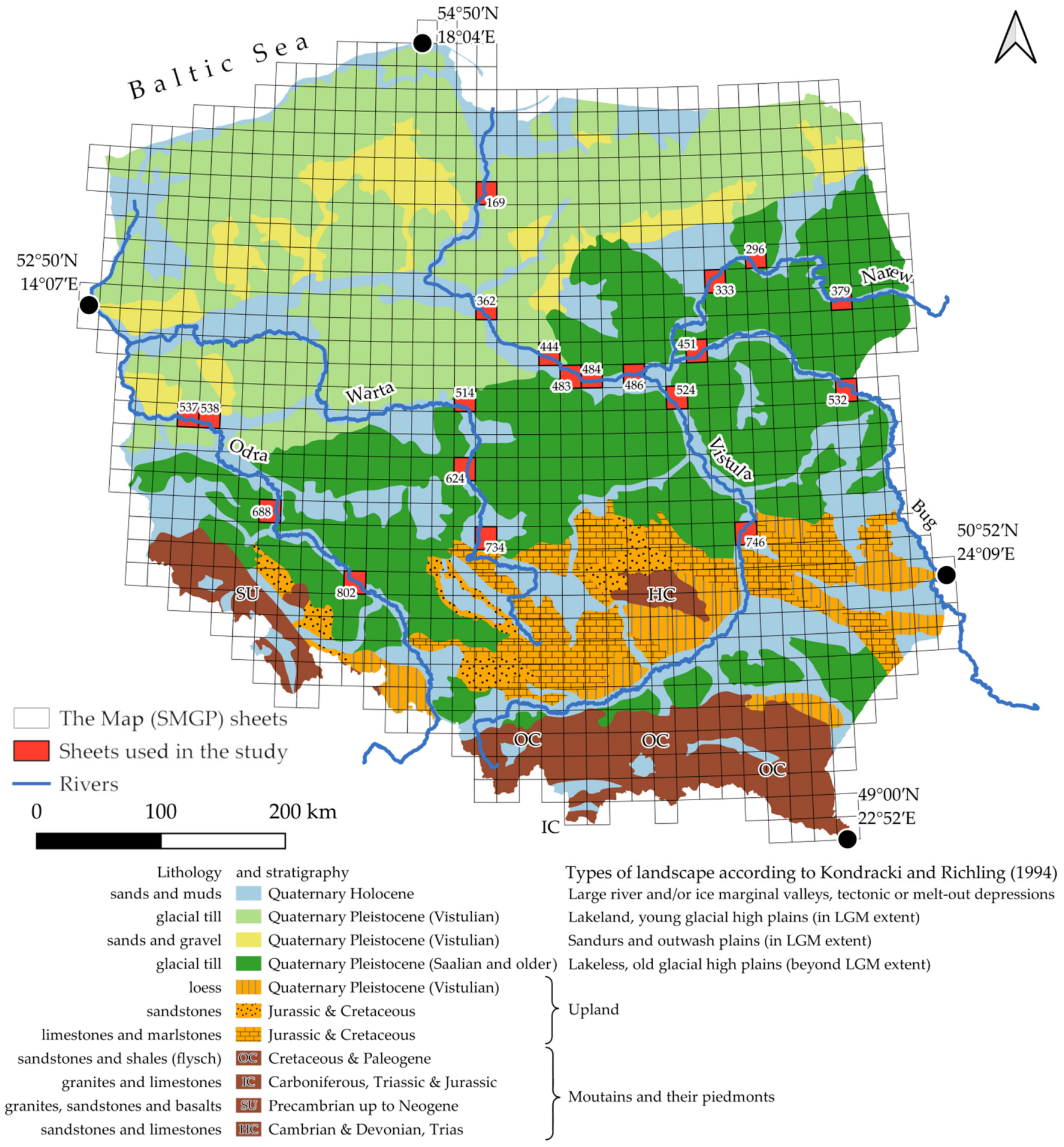

Figure 1. Physical map of Poland, Kondracki and Richling [46], with five the largest Polish rivers (Odra, Warta, Vistula, Bug, and Narew) and 1069 sheets of the Map (Detailed Geological Map of Poland, in Polish: SMGP), among them 20 sheets used in the study. LGM-Last Glacial Maximum, OC—Outer Carpathians Mts., IC—Inner Carpathian Mts., SU—Sudetes, HC-Holy Cross Mts.

\section{Results and Discussion}

We found that the specific and repetitive pattern of geological setting is in 20 sheets $(2 \%)$ (red squares in Figure 1). Moreover, $75 \%$ of them occur in The Belt of Great Valleys [36] (dark green on the map in Figure 1). Furthermore, 25\% of cases are located northerly, in the Lakeland-yellow-green on the map in Figure 1. 
These results can be biased by the frequency of the geological cross-sections through the river valley with the deep boreholes drilled on the floodplain. One of the reasons is the fact that in the 1950s there was a concept of building 9 dams in the Lower Vistula River valley (The Lower Vistula Cascade, pol. Kaskada Dolnej Wisły) $[47,48]$. Another reason can be a larger number of bridges crossing the Lower Vistula River in comparison to the Middle Vistula, Bug, and Narew Rivers. Fieldworks in the locations of the designed dams and bridges resulted in an increase in the number of deep boreholes drilled at the bottom of the valley in the Lower Vistula River. These boreholes induced authors of The Map to draw the geological cross-section through the river valley or enhanced the projection of geological setting under the floodplain. Geological structures under the bottom of the Lower Vistula River valley are probably better documented than in the other large Polish rivers.

The specific pattern revealed in our study looks like the river channel sits atop the bedrock or non-alluvial protrusion, and it repeats in all the large rivers of PolandFigures 2-7.

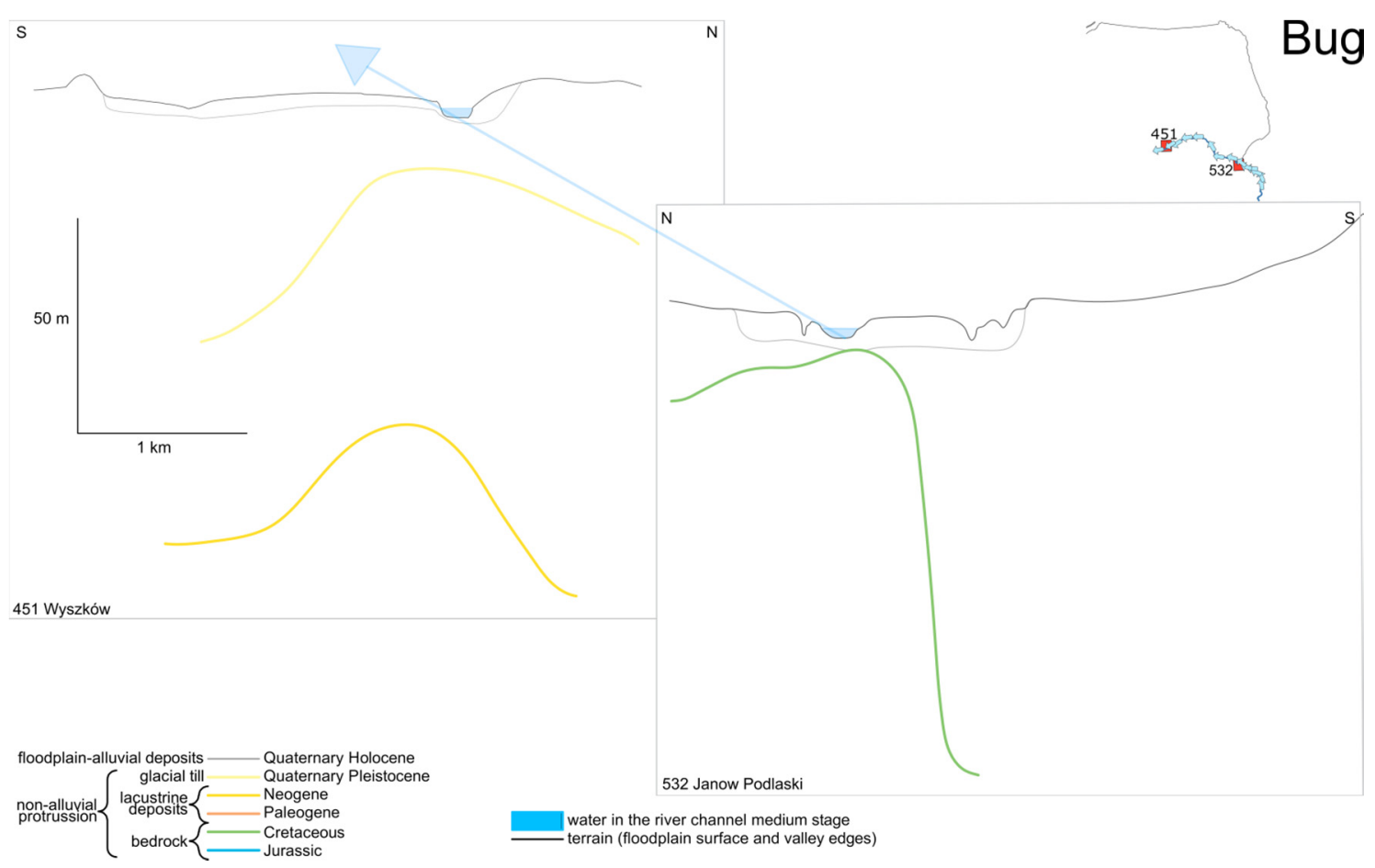

Figure 2. Geological cross-sections through the Bug river valley, according to [49,50]. Each cross-section presents: water in the river channel during medium stage (blue body); schematic river channel with flow direction (blue line) the valley profile graph with the floodplain surface and the valley's walls (black), alluvial cover of the floodplain (grey) and non-alluvial protrusion underneath. The color of the non-alluvial protrusion indicates its age according to the stratigraphic chart [43].

In the Bug river, the protrusions were identified on two geological cross-sections located near Wyszków [49] and near Janów Podlaski [50]. The simplified cross-sections are shown in Figure 2. The protrusion near Janów Podlaski is located in the Podlasie Gap of the Bug River (in Polish: Podlaski Przełom Bugu) [51] and is visible as a single hump built on Upper Cretaceous chalk rocks. The next protrusion near Wyszków is a Pleistocene glacial till hump and it repeats its shape underneath in the Neogene (Miocene and Pliocene) lacustrine clays. The Cretaceous bedrock is just around $2 \mathrm{~m}$ below the river channel bottom in the Podlasie Gap of the Bug River. Non-alluvial sediments in the Bug river reach near Wyszków are at a depth of ca. $10 \mathrm{~m}$ (Pleistocene) and ca. $70 \mathrm{~m}$ (Miocene and Pliocene). 


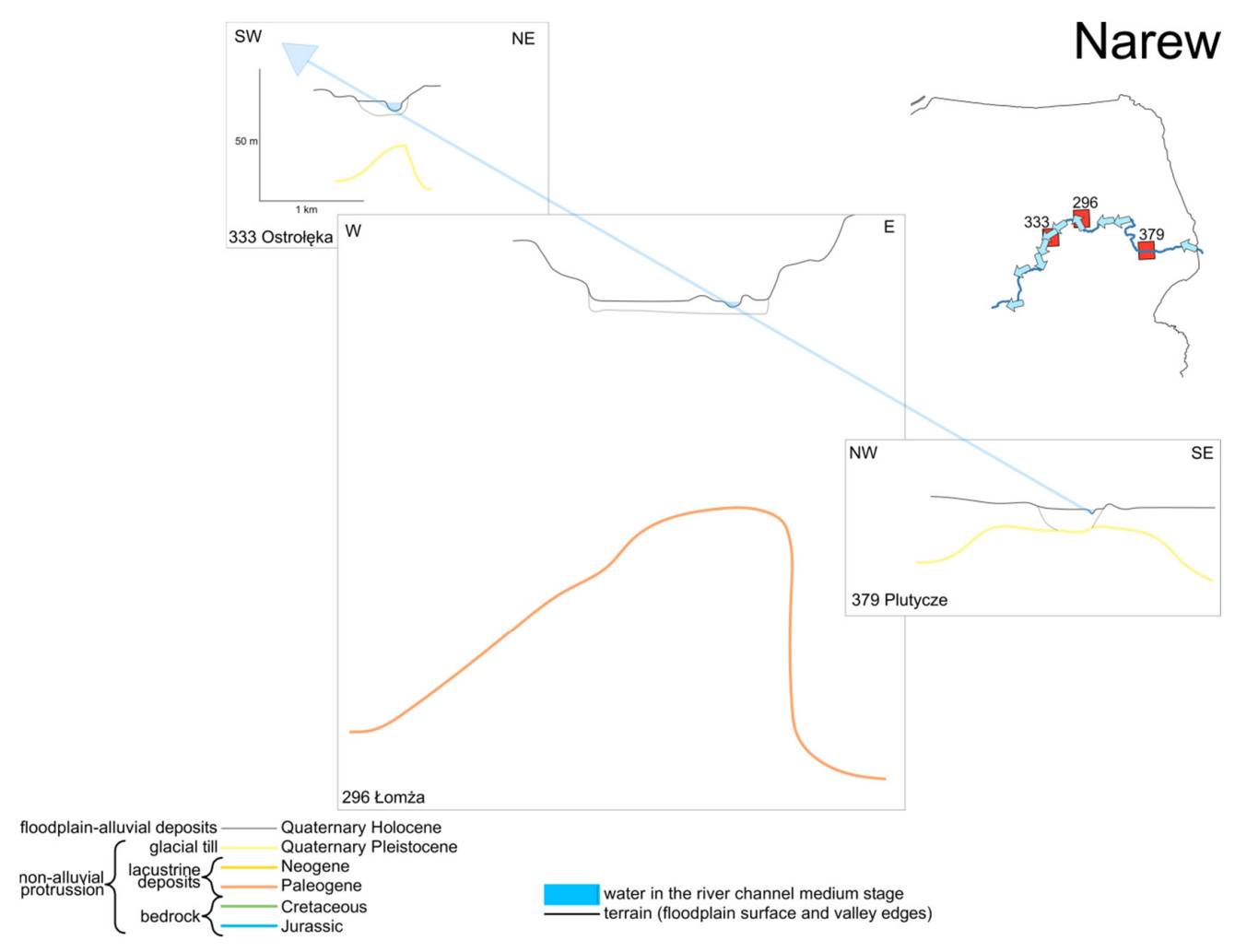

Figure 3. Geological cross-sections through the Narew river valley, according to [52-54]. Each cross-section presents on: water in the river channel during medium stage (blue body); schematic river channel with flow direction (blue line) the valley profile graph with the floodplain surface and the valley's walls (black), alluvial cover of the floodplain (grey) and non-alluvial protrusion underneath. The color of the non-alluvial protrusion indicates its age according to the stratigraphic chart [43].

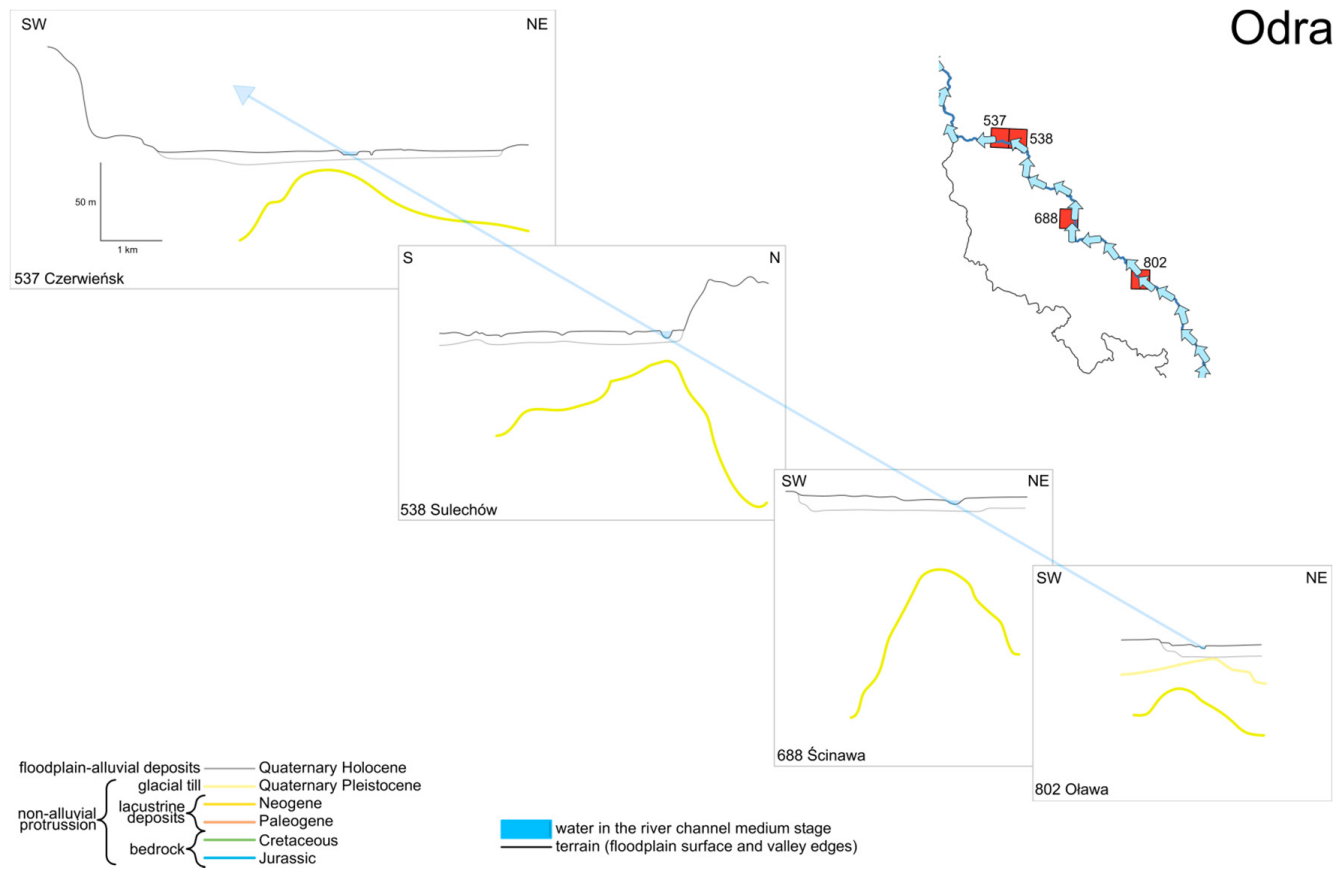

Figure 4. Geological cross-sections through the Odra river valley, according to [55-58]. Each cross-section presents: water in the river channel during medium stage (blue body); schematic river channel with flow direction (blue line) the valley profile graph with the floodplain surface and the valley's walls (black), alluvial cover of the floodplain (grey) and non-alluvial protrusion underneath. The color of the non-alluvial protrusion indicates its age according to the stratigraphic chart [43]. 


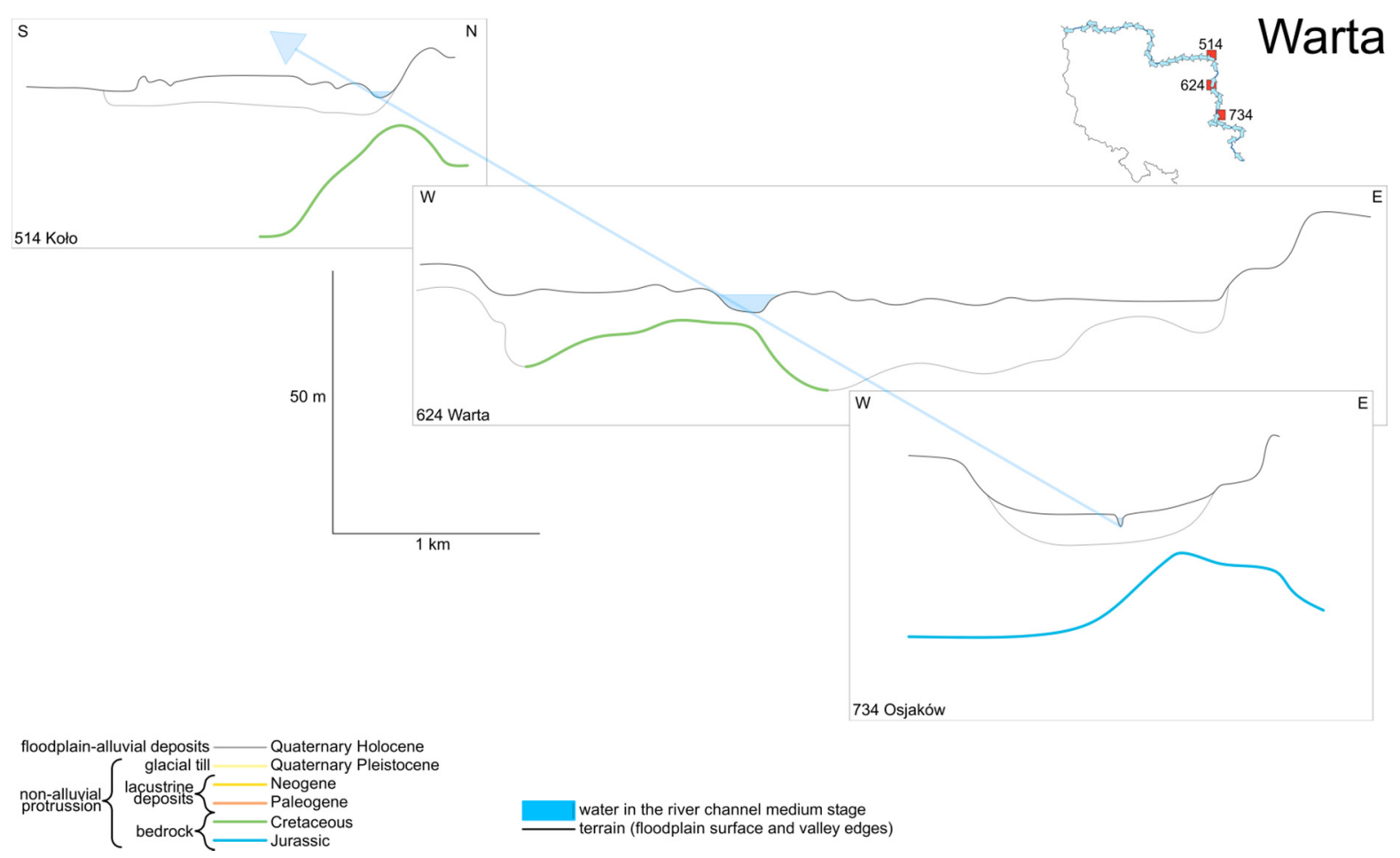

Figure 5. Geological cross-sections through the Warta river valley, according to [59-61]. Each cross-section presents: water in the river channel during medium stage (blue body); schematic river channel with flow direction (blue line) the valley profile graph with the floodplain surface and the valley's walls (black), alluvial cover of the floodplain (grey) and non-alluvial protrusion underneath. The color of the non-alluvial protrusion indicates its age according to the stratigraphic chart [43].

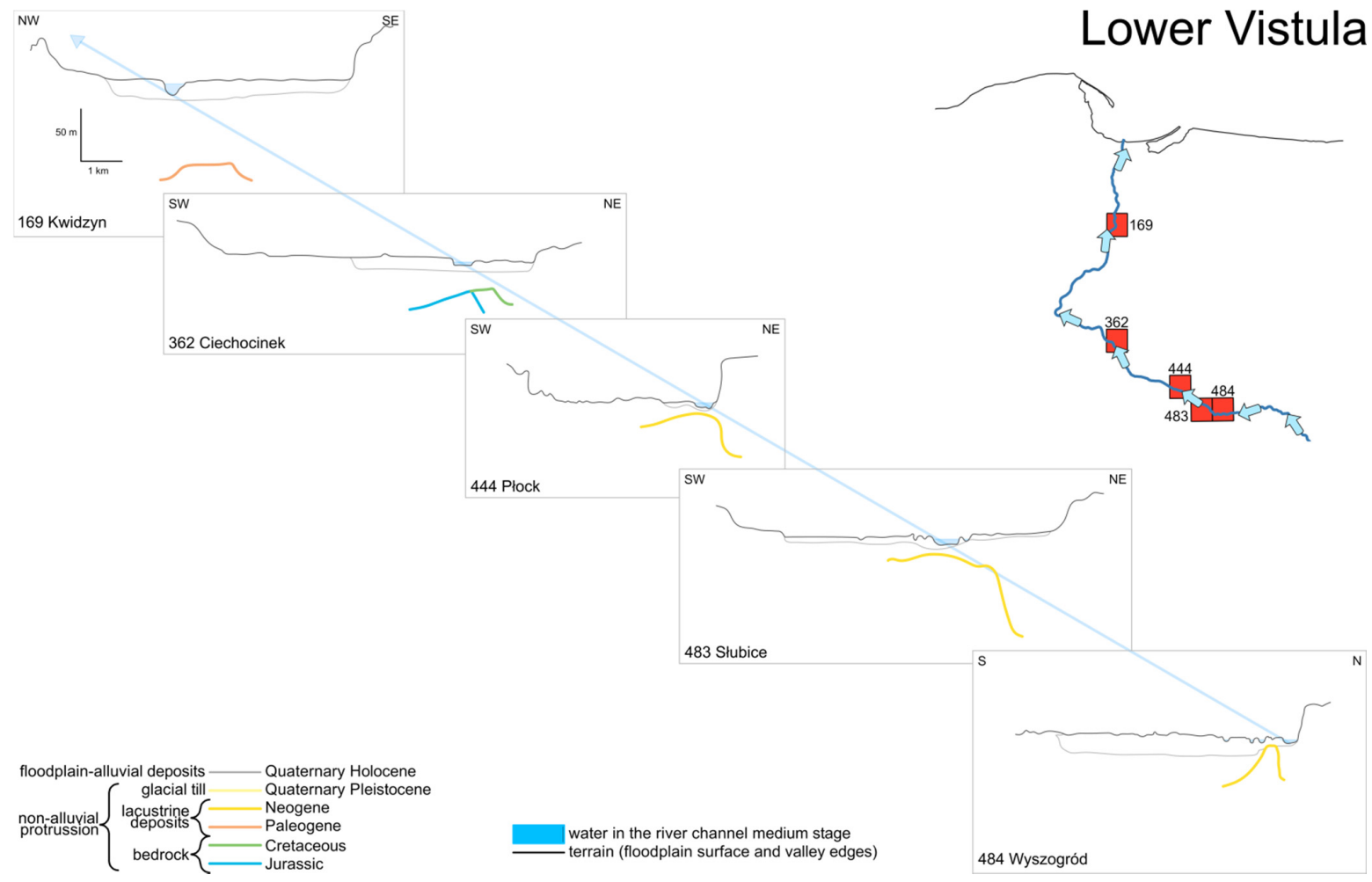

Figure 6. Geological cross-sections through the Middle Vistula River valley, according to [62-66]. Each cross-section presents: water in the river channel during medium stage (blue body); schematic river channel with flow direction (blue line) the valley profile graph with the floodplain surface and the valley's walls (black), alluvial cover of the floodplain (grey) and non-alluvial protrusion underneath. The color of the non-alluvial protrusion indicates its age according to the stratigraphic chart [43]. 
$s$

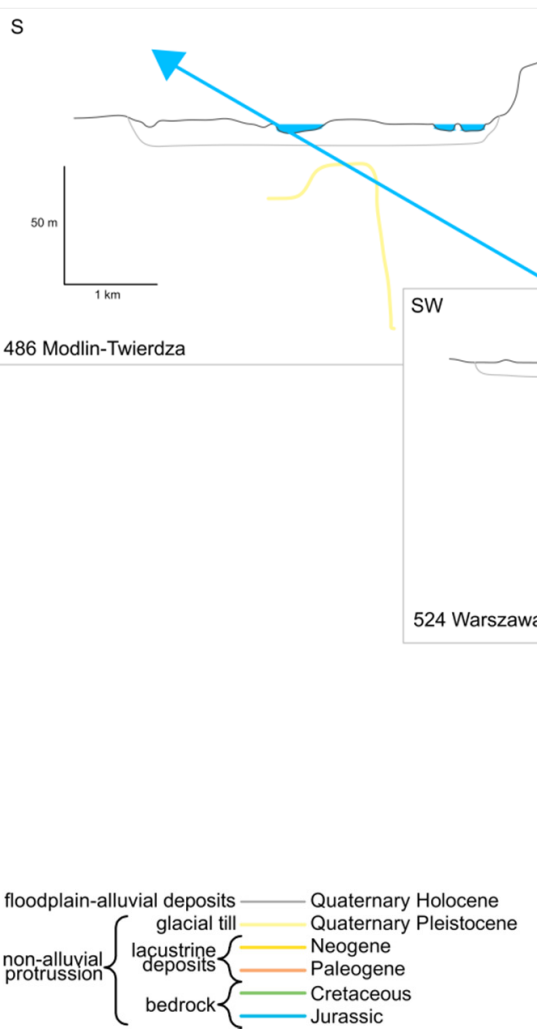

N

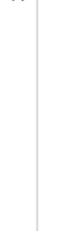

\section{Middle Vistula}

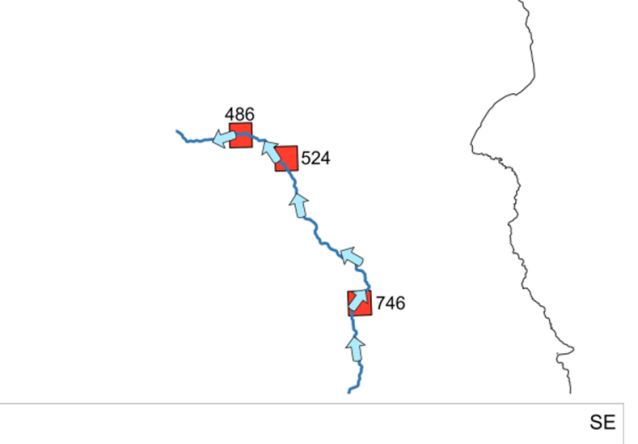

NW

NE

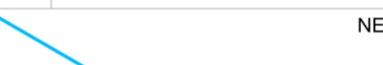

"

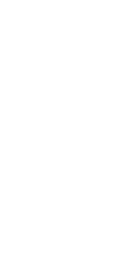

746 Kazimierz Dolny

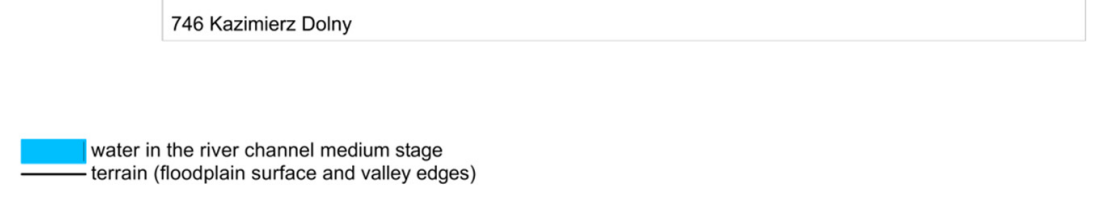

Figure 7. Geological cross-sections through the Middle Vistula River valley, according to [67-69]. Each cross-section presents: water in the river channel during medium stage (blue body); schematic river channel with flow direction (blue line) the valley profile graph with the floodplain surface and the valley's walls (black), alluvial cover of the floodplain (grey) and non-alluvial protrusion underneath. The color of the non-alluvial protrusion indicates its age according to the stratigraphic chart [43].

The non-alluvial protrusions under the Narew river channel Figure 3 were revealed at three locations: Łomża [52], Ostrołęka [53], and Plutycze [54]. The protrusion near Łomża forms a hump located deeply, ca. $100 \mathrm{~m}$ below the channel bottom. It consists of Paleogene (Eocene and Oligocene) lacustrine sediments. The protrusions near Ostrołeka and Plutycze are built of Pleistocene glacial tills, located 10-20 m below the river channel bottom.

The analysis of the geological cross-sections through the Odra river valley Figure 4 revealed four protrusions near Czerwieńsk [55], Sulechów [56], Ścinawa [57], and Oława [58]. At all four sites, the river flows atop the Neogene (Miocene) humps located less than $50 \mathrm{~m}$ below the bottom of the river channel. The protrusion near Olawa is located just a few meters below the river channel bottom and it is built of Miocene lacustrine deposits and Pleistocene (Elsterian) glacial tills. The protrusion near Ścinawa and Sulechów are made of Miocene lacustrine sediments.

The Warta river channel flows atop the Mesozoic protrusions, as revealed by three geological cross-sections in Figure 5. The first protrusion, near Koło [59], is built of Upper Cretaceous marlstones, limestones, and sandstones and it can be found around $10 \mathrm{~m}$ below the bottom of the river channel. The next one has similar lithology and stratigraphy (Maastrichtian) to that near Koło, but it is located near Warta (city) [60]. It is placed just $5 \mathrm{~m}$ below the river channel bottom. The third one is built of limestones, but older than those mentioned above-Upper Jurassic (Upper Oxford). It is located near Osjaków [61]. The protrusion is also shallowly located, just $5 \mathrm{~m}$ below the bottom of the river channel.

The analysis of the geological cross-sections through the Vistula river revealed 8 reaches with a specific pattern of geological setting. In order to increase the readability of our 
results, the river was divided into the Lower Vistula (5 reaches-Figure 6) and the Middle Vistula (3 reaches-Figure 7).

The protrusions on the Lower Vistula River are located near Kwidzyn [62], Ciechocinek [63], Płock [64], Słubice [65], and Wyszogród [66] as shown in Figure 6. The protrusion near Kwidzyn is located very deeply (70 $\mathrm{m}$ below the river channel bottom) and it is made of lacustrine deposits (glauconitic sands with phosphorites and clays) of the Paleogene (Oligocene) age. The protrusion near Ciechocinek is the oldest in the Lower Vistula river. It is made of Lower Cretaceous limestones and shales and Upper Jurassic (Portland) marlstones, mudstones and limestones located $20 \mathrm{~m}$ below the bottom of the river channel. The next protrusions are located adjacent to Last Glacial Maximum (LGM) margin near Płock and Słubice. They consist of Negoene (Pliocene) lacustrine clays. Their surface can be found just 10-20 m below the bottom of the river channel. The protrusion near Wyszogród comprises the river channel bottom and it is made of Neogene (Miocene) lacustrine clays.

The Middle Vistula river has three protrusions according to The Map: near Modlin [67], in the southern part of Warsaw [68], and near Kazimierz Dolny [69] visible in Figure 7. The protrusion near Modlin is made of ice-dammed lake clays dated on the Lower Pleistocene (Elsterian) and it is located $20 \mathrm{~m}$ below the river channel bottom. Protrusion near the southern margin of Warsaw is built of Neogene (Pliocene) lacustrine clays and it can be found $10 \mathrm{~m}$ below the bottom of the river channel. The Kazimierz Dolny protrusion is the oldest in the middle reach of the Vistula river-Upper Cretaceous (Maastricht). The hump is made of chalk (limestones) and it is located around $15 \mathrm{~m}$ below the bottom of the river channel.

A fact of the specific location (Figure 1) of the river valley reaches with the repetitive, specific pattern of geological setting (Figures 2-7) can be a result of several advances of Fennoscandian Ice Sheet in Polish Lowland [18]. A continental glaciation is a very significant and long-lasting (a timescale of Quaternary) disturbance for the fluvial systems, because glacial till completely covers the initial (preglacial) surface. Usually, after ice-sheet retreat, an incision occurs, and a new river valley has to be formed again. Bedrock protrusion can serve in such a case as the limit of an incision. Many large river valleys in Poland are landforms inherited from the ice-marginal valleys [70], which were impacted by fluvial and glaciofluvial deposition during the last (Vistulian; from German also: Weichselian) glaciation. This deposition formed the upper terraces that reworked the fluvial setting in the river valley and enabled the later floodplain formation in Holocene [30]. The fluvial system can recover therefore to the initial state but in different postglacial frames. However, the river channel tends to anchor on the non-alluvial protrusion again.

Hauer and Pulg [71,72] found a similar pattern in the Norwegian rivers and they linked its origin with long-lasting river incision into fluvial deposits that has exposed glacial tills buried underneath. However, Hauer and Pulg [71,72] described such non-fluvial protrusions in the longitudinal profile of mountainous streams in Norway. The results of our study reveal the existence of non-fluvial protrusion in the transverse profile of the river valley and locate the protrusion exactly below the river channel.

Our findings can prove useful in understanding the geological control of Holocene flood dynamics in large, alluvial valleys (Figure 8). We distinguish two different types of flood: (I) events induced by ice-jam when relatively small discharge in the channel can involve overbank flow on the floodplain (Figure 8-left side); and (II) rainfall or snow-melt events with very high discharge in the river (Figure 8-right side).

(I) Jamming of the river channel by ice leads to scouring. When scour reaches the bedrock protrusion, it cannot be eroded due to high resistance and an overbank flow initiates on the floodplain surface. The overbank flow cuts in the floodplain surface an erosional through, a landform that is parallel to the main channel and serves as the temporary sidearm. At the final phase of the flood, a filling process occurs at the bottom of the channel. Such a type of flood tends to occur very often, and it has a local extent. 

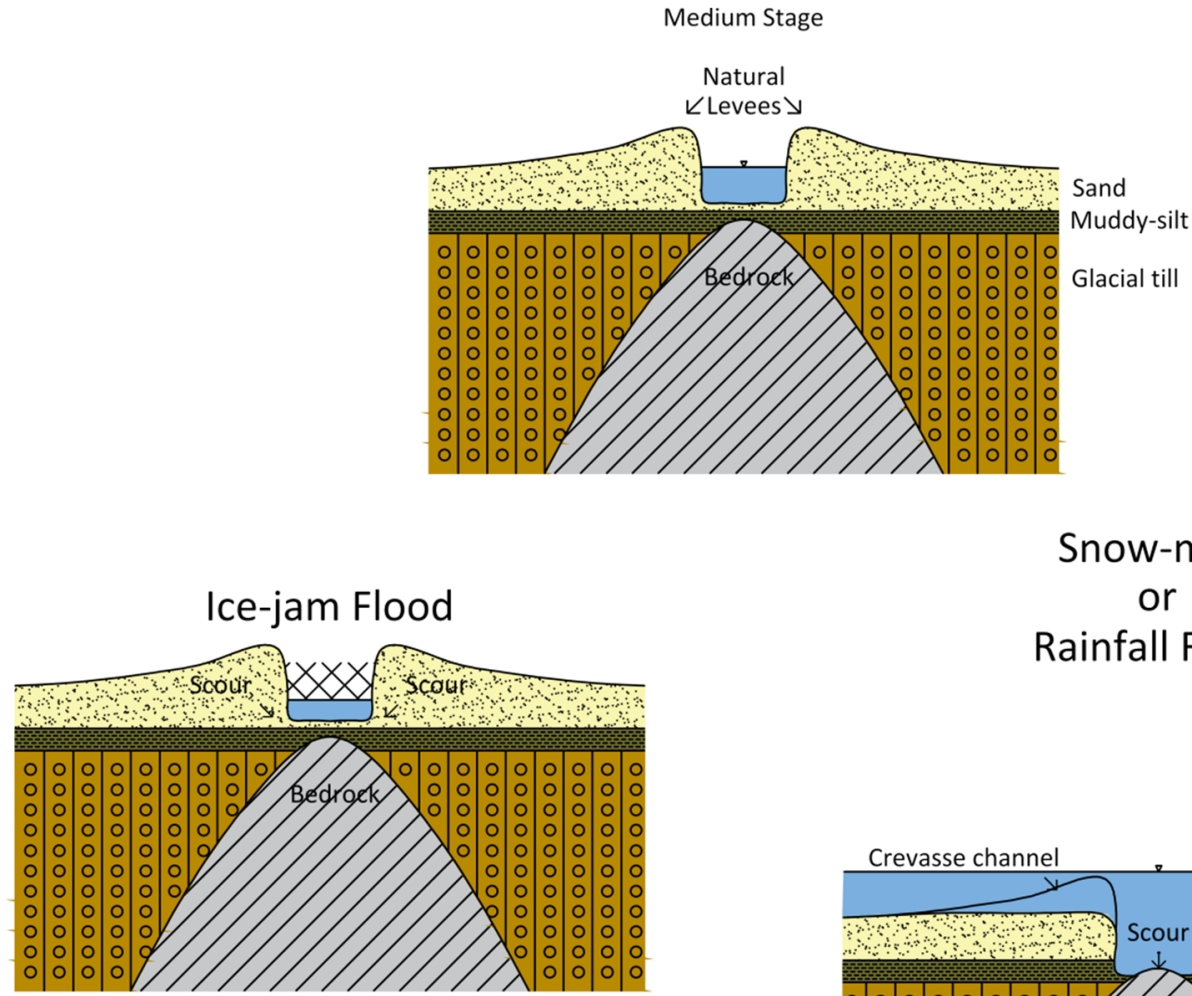

\section{Snow-melt \\ or \\ Rainfall Flood}
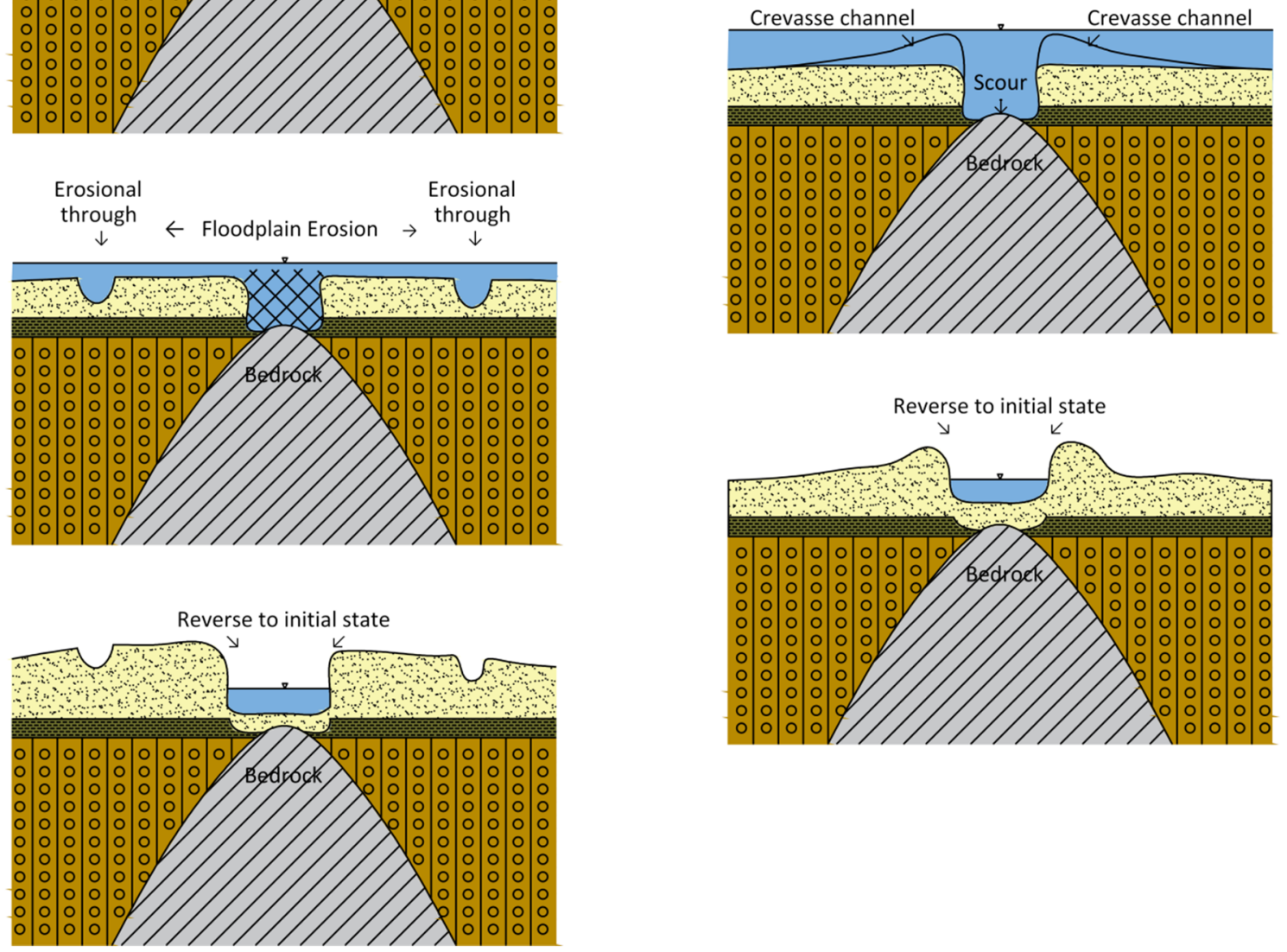

Figure 8. Idealized, schematic geological cross-section of the large, alluvial river valley with the river channel anchored atop bedrock (or non-alluvial protrusion) during the ice-jam floods (on the left) and snowmelt or rainfall floods (on the right).

(II) Snowmelt or rainfall flood acts, in opposite to ice-jams, in the non-confined river channel. Overbank flow on the floodplain occurs only on the condition of very high discharge and it can initiate after breaching of natural levees at the banks of the river channel. Scour reaches the bedrock protrusion as in the case of ice-jam, but overbank erosion on the floodplain is limited to the crevasse channel cut in the natural levee. The erosional landforms can be masked by the latter rebuild of levees. 
The pattern of geological setting, which we reveal in Figures 2-7 and idealized on the scheme in Figure 8, can be adopted as an environmental framework by hydrotechnical engineers who aim to develop instream river training $[73,74]$. Such a design practice faces a problem of too high stream power [39,75-85] in the channel which leads to erosion. There are few concepts of energy dissipation of the stream. One of them involves putting the concrete baffles or micro groynes into the channel $[73,74,86]$.

The present state of the art in science is not enough to explain or even understand the origin of the specific geological pattern of river channel flowing atop bedrock protrusion we present in this study. If this pattern exists more widely in fluvial systems on Earth, some basic principles of fluvial geomorphology should be revised. The "differential erosion" concept says that a river uses less resistant (to erosion) bedrock to form its channel and whole fluvial valley. The results of our study prove something different, that rivers try harder. Rivers tend to flow on the most resistant (to erosion) rock available under the alluvial belt.

The study area underwent glaciotectonic modelling [87-89] and a postglacial rebound, glacial isostatic adjustment [90], which undoubtedly modified non-alluvial protrusions, or even formed these structures from the relatively flat preglacial surface (Figure 9).

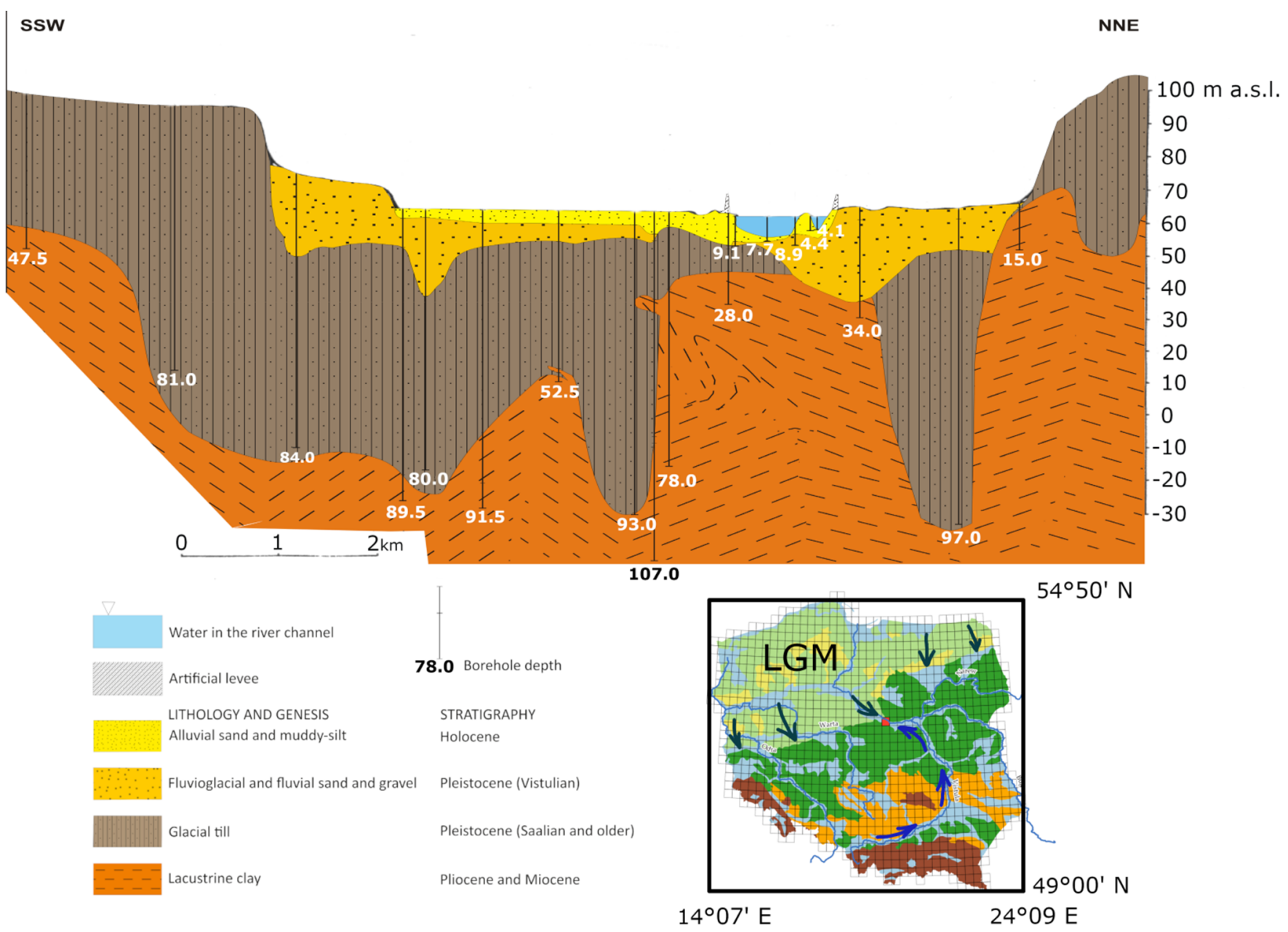

Figure 9. The geological pattern of the river channel flowing atop the non-alluvial protrusion on the cross-section through the Lower Vistula River at Troszyn-Wykowo (near Płock) [91], modified by [92] with the locator map of Poland from Figure 1. The red rectangle indicates the location of the cross-section exactly at the margin of the LGM paleo-ice stream (Vistula Ice Stream—compare [89,93]). 


\section{Conclusions}

A basic source of geological information in Poland (SMGP; The Map) enables us to determine the specific pattern of geological setting under the large, alluvial river valleys. The pattern can be identified in the in $2 \%$ sheets of The Map, however, it exists under all the large rivers of Poland: Odra, Warta, Middle Vistula, Narew, Bug, and Lower Vistula.

In a wide and alluvial valley, a river tends to flow above the protrusion of non-alluvial sediments which are the most resistant to erosion and the oldest ones among different deposits available under the alluvial belt.

The geographical distribution of the pattern in Poland indicates its dominance in the broad valleys which are cut by the rivers flowing through the old-glacial (Pleistocene but beyond the LGM) high plains-a type of morainic plateau without postglacial lakes. This location used to be named The Belt of Great Valleys.

The geological pattern controls on the Holocene incision of large rivers, what we regard as a reasonable driver of fluvial resistance [16]. The pattern also controls on floodplain recovery after a disturbance because a river channel stays at the same location in the alluvial belt during thousands of flood events in the Holocene. The control of incision resistance combined with the ability of floodplain recovery create the resilience of the studied fluvial systems, as proposed by [94].

A reason for horizontal stability of the channel exactly atop the non-alluvial protrusion during a very long period is unknown. Further research on this topic is necessary.

The time of lateral stability of the river channel is the Holocene in the LGM extent, but beyond the LGM extent, it can last longer, in some cases at least since the younger interglacial periods of the Pleistocene, or even since the preglacial period of Quaternary.

Our conception of reversed "differential erosion" on Polish Lowland should be verified through a perspective without tectonic quiescence, similar to other revisions of the old-fashioned topics in geomorphology, eg., revisions of planation surfaces in the Outer Carpathians [27] and in Northern Etiopia [95].

Author Contributions: Conceptualization, G.W.; methodology, J.S.B. and G.W.; validation, G.W.; formal analysis, J.S.B. and G.W.; investigation, J.S.B.; data curation, J.S.B.; writing—original draft preparation, G.W. and J.S.B.; writing-review and editing, G.W. and J.S.B.; visualization, J.S.B.; supervision, G.W. All authors have read and agreed to the published version of the manuscript.

Funding: This research and APC was funded from a subsidy of the Ministry of the Interior and Administration, Poland to The Main School of Fire Service in Warsaw and the Ministry of Education and Science Poland to Warsaw University of Life Sciences-SGGW. National Science Centre (NCN, Poland) supported work on geological cross-section presented in Figure 9 by the research project 2012/07/N/ST10/03294 granted to G. Wierzbicki (Preludium 4).

Data Availability Statement: Publicly available datasets were analyzed in this study. The data can be found in Central Geological Database of Polish Geological Institute-National Research Institute, available at: http:/ / baza.pgi.gov.pl/ (accessed on 1 February 2021).

Acknowledgments: The authors would like to thank Tomasz Falkowski for the inspiration to search for the geological pattern under the large rivers in Poland. The inspiration came to the mind of the 2nd author after having a look at the Bug River geological cross-section drawn by Tomasz Falkowski and Piotr Ostrowski. The 1st author would like to thank Hanna and Stefan Mikulik for inspiration to study Water Engineering and Management. The second author thanks also Michał Wierzbicki for indicating the instream river training design. The authors acknowledge the valuable comments and suggestions received from two anonymous reviewers. The paper was submitted to the Special Issue "Fluvial Geomorphology and River Management" edited by Salvatore Ivo Giano.

Conflicts of Interest: The authors declare no conflict of interest.

\section{References}

1. Tockner, K.; Stanford, J.A. Riverine flood plains: Present state and future trends. Environ. Conserv. 2002, 29, 308-330. [CrossRef]

2. Balogh, M.; Kiss, T.; Fiala, K.; Fehérváry, I. Floodplain forms along the lowland Maros River, Hungary. Geogr. Pol. 2020, 93, 51-68. [CrossRef] 
3. Izumida, A.; Uchiyama, S.; Sugai, T. Application of UAV-SfM photogrammetry and aerial lidar to a disastrous flood: Repeated topographic measurement of a newly formed crevasse splay of the Kinu River, central Japan. Nat. Hazards Earth Syst. Sci. 2017, 17, 1505-1519. [CrossRef]

4. Gouw, M.J.P.; Autin, W.J. Alluvial architecture of the Holocene Lower Mississippi Valley (U.S.A.) and a comparison with the Rhine-Meuse delta (The Netherlands). Sediment. Geol. 2008, 204, 106-121. [CrossRef]

5. Lóczy, D.; Pirkhoffer, E.; Gyenizse, P. Geomorphometric floodplain classification in a hill region of Hungary. Geomorphology 2012, 147-148, 61-72. [CrossRef]

6. Macklin, M.G.; Benito, G.; Gregory, K.J.; Johnstone, E.; Lewin, J.; Michczyńska, D.J.; Soja, R.; Starkel, L.; Thorndycraft, V.R. Past hydrological events reflected in the Holocene fluvial record of Europe. CATENA 2006, 66, 145-154. [CrossRef]

7. Lombardi, R.; Davis, L.; Stinchcomb, G.E.; Munoz, S.E.; Stewart, L.; Therrell, M.D. Fluvial activity in major river basins of the eastern United States during the Holocene. Holocene 2020, 30, 1279-1295. [CrossRef]

8. Price, S.J.; Ford, J.R.; Cooper, A.H.; Neal, C. Humans as major geological and geomorphological agents in the Anthropocene: The significance of artificial ground in Great Britain. Philos. Trans. R. Soc. A Math. Phys. Eng. Sci. 2011, 369, 1056-1084. [CrossRef] [PubMed]

9. Brown, A.G.; Tooth, S.; Bullard, J.E.; Thomas, D.S.G.; Chiverrell, R.C.; Plater, A.J.; Murton, J.; Thorndycraft, V.R.; Tarolli, P.; Rose, J.; et al. The geomorphology of the Anthropocene: Emergence, status and implications. Earth Surf. Process. Landf. 2017, 42, 71-90. [CrossRef]

10. Nikolov, T.; Hristova, R. Anthropocene versus Holocene in the Light of the Principles of Stratigraph. C. R. Acad. Bulg. Sci. 2020, 73, 236-243. [CrossRef]

11. Falkowski, T.; Ostrowski, P.; Siwicki, P.; Brach, M. Channel morphology changes and their relationship to valley bottom geology and human interventions; a case study from the Vistula Valley in Warsaw, Poland. Geomorphology 2017, 297, 100-111. [CrossRef]

12. Falkowski, T.; Ostrowski, P.; Bogucki, M.; Karczmarz, D. The trends in the main thalweg path of selected reaches of the Middle Vistula River, and their relationships to the geological structure of river channel zone. Open Geosci. 2018, 10, 554-564. [CrossRef]

13. Wierzbicki, G.; Ostrowski, P.; Falkowski, T.; Mazgajski, M. Geological setting control of flood dynamics in lowland rivers (Poland). Sci. Total Environ. 2018, 636, 367-382. [CrossRef]

14. Bujakowski, F.; Falkowski, T. Hydrogeological Analysis Supported by Remote Sensing Methods as A Tool for Assessing the Safety of Embankments (Case Study from Vistula River Valley, Poland). Water 2019, 11, 266. [CrossRef]

15. Ostrowski, P.; Falkowski, T. Application of Remote Sensing Methods to Study the Relief of Lowland River Valleys with a Complex Geological Structure-A Case Study of the Bug River. Water 2020, 12, 487. [CrossRef]

16. Falkowski, T. Alluvial bottom geology inferred as a factor controlling channel flow along the Middle Vistula River, Poland. Geol. Q. 2007, 51, 91-102.

17. Falkowski, T. The application of geomorphological analysis of the Vistula River, Poland in the evaluation of the safety regulation structures. Acta Geol. Pol. 2007, 57, 377-390.

18. Weckwerth, P. Fluvial responses to the Weichselian ice sheet advances and retreats: Implications for understanding river paleohydrology and pattern changes in Central Poland. Int. J. Earth Sci. 2018, 107, 1407-1429. [CrossRef]

19. Goudie, A. Alphabetical glossary of geomorphology, version 1. Electron. Ed. Int. Assoc. Geomorphol. 2014, $2014,84$.

20. Yunus, A.P. Geomorphic and lithologic control on bedrock channels in drainage basins of the Western Arabian Peninsula. Arab. J. Geosci. 2016, 9, 133. [CrossRef]

21. Migoń, P.; Jancewicz, K.; Różycka, M.; Duszyński, F.; Kasprzak, M. Large-scale slope remodelling by landslides-Geomorphic diversity and geological controls, Kamienne Mts., Central Europe. Geomorphology 2017, 289, 134-151. [CrossRef]

22. Carlson, B.M.; Schermer, E.R.; Amos, C.B.; Stephenson, W.J.; Sherrod, B.L.; Mahan, S.A. Holocene fault reactivation in the eastern cascades, Washington. Bull. Seismol. Soc. Am. 2018, 108, 2614-2633. [CrossRef]

23. Glaus, G.; Delunel, R.; Stutenbecker, L.; Akçar, N.; Christl, M.; Schlunegger, F. Differential erosion and sediment fluxes in the Landquart basin and possible relationships to lithology and tectonic controls. Swiss J. Geosci. 2019, 112, 453-473. [CrossRef]

24. Ngapna, M.N.; Owona, S.; Owono, F.M.; Ateba, C.B.; Tsimi, V.M.; Ondoa, J.M.; Ekodeck, G.E. Assessment of relative active tectonics in Edea-Eseka region (SW Cameroon, Central Africa). J. Afr. Earth Sci. 2020, 164. [CrossRef]

25. Gaidzik, K.; Herrera, R.M.T. Geomorphic indices and relative tectonic uplift in the Guerrero sector of the Mexican forearc. Geosci. Front. 2017, 8, 885-902. [CrossRef]

26. Starkel, L. The age of the stages of development of the relief of the Polish Carpathians in the light of the most recent geological investigations. Stud. Geomorphol. Carpath. Balc. 1969, 3, 33-44.

27. Zuchiewicz, W. Planation surfaces in the Polish Carpatians: Myth or reality? Geogr. Pol. 2011, 84, 155-178. [CrossRef]

28. Andreucci, B.; Castelluccio, A.; Jankowski, L.; Mazzoli, S.; Szaniawski, R.; Zattin, M. Burial and exhumation history of the Polish Outer Carpathians: Discriminating the role of thrusting and post-thrusting extension. Tectonophysics 2013, 608, 866-883. [CrossRef]

29. Wierzbicki, G.; Ostrowski, P.; Falkowski, T. Applying floodplain geomorphology to flood management (The Lower Vistula River upstream from Plock, Poland). Open Geosci. 2020, 12, 1003-1016. [CrossRef]

30. Wierzbicki, G.; Ostrowski, P.; Bartold, P.; Bujakowski, F.; Falkowski, T.; Osiński, P. Urban geomorphology of the Vistula River valley in Warsaw. J. Maps 2021, 1-16. [CrossRef] 
31. Stroeven, A.P.; Hättestrand, C.; Kleman, J.; Heyman, J.; Fabel, D.; Fredin, O.; Goodfellow, B.W.; Harbor, J.M.; Jansen, J.D.; Olsen, L.; et al. Deglaciation of Fennoscandia. Quat. Sci. Rev. 2016, 147, 91-121. [CrossRef]

32. Patton, H.; Hubbard, A.; Andreassen, K.; Auriac, A.; Whitehouse, P.L.; Stroeven, A.P.; Shackleton, C.; Winsborrow, M.; Heyman, J.; Hall, A.M. Deglaciation of the Eurasian ice sheet complex. Quat. Sci. Rev. 2017, 169, 148-172. [CrossRef]

33. Dyke, A.S.; Andrews, J.T.; Clark, P.U.; England, J.H.; Miller, G.H.; Shaw, J.; Veillette, J.J. The Laurentide and Innuitian ice sheets during the Last Glacial Maximum. Quat. Sci. Rev. 2002, 21, 9-31. [CrossRef]

34. Marshall, S.J.; James, T.S.; Clarke, G.K.C. North American Ice Sheet reconstructions at the Last Glacial Maximum. Quat. Sci. Rev. 2002, 21, 175-192. [CrossRef]

35. Ber, A. The detailed geological map of Poland 1:50,000: The history, present and future. Prz. Geol. 2005, 53, 903-906.

36. Sawicki, L. Terminologja Regjonalna ziem Polskich, Uchwalona i Polecona Przez Zjazd Geograficzny, Zorganizowany Staraniem Tow. Naucz. Szk. Wyż. w Krakowie 1922; Nakładem Ksiegarni Geograficznej Orbis: Warsaw, Poland, 1922.

37. Miller, B.A.; Juilleret, J. The colluvium and alluvium problem: Historical review and current state of definitions. Earth Sci. Rev. 2020, 209. [CrossRef]

38. Hjulström, F. Studies of the Morphological Activity of Rivers as Illustrated by the River Fyris. Geogr. Ann. 1936, 18, 121-123. [CrossRef]

39. Worrall, F.; Burt, T.P.; Hancock, G.R.; Howden, N.J.K.; Wainwright, J. The problem of underpowered rivers. Earth Surf. Process. Landf. 2020, 45, 3869-3878. [CrossRef]

40. Bąkowska, A.; Dobak, D.; Gawriuczenkow, I.; Kiełbasiński, K.; Szczepański, T.; Trzciński, J.; Wójcik, E.; Zawrzykraj, P. Stressstrain behaviour analysis of Middle Polish glacial tills from Warsaw (Poland) based on the interpretation of advanced field and laboratory tests. Acta Geol. Pol. 2016, 66, 562-586. [CrossRef]

41. Dobak, P.; Kiełbasiński, K.; Szczepański, T.; Zawrzykraj, P. Verification of compressibility and consolidation parameters of varved clays from Radzymin (Central Poland) based on direct observations of settlements of road embankment. Open Geosci. 2018, 10, 911-924. [CrossRef]

42. Rabarijoely, S. Rigidity of "Warsaw clay" from the Poznań Formation determined by in situ tests. Open Geosci. 2020, 12, 1274-1285. [CrossRef]

43. Cohen, K.M.; Finney, S.C.; Gibbard, P.L.; Fan, J.X. The ICS International Chronostratigraphic Chart. Episodes 2013, 36, 199-204. [CrossRef] [PubMed]

44. QGIS Development Team. QGIS 3.10 LTR Geographic Information System. Open Source Geospatial Foundation Projects. 2019. Available online: http:/ / qgis.osgeo.org/ (accessed on 1 February 2021).

45. Inkscape Project, Inkscape. 2020. Available online: https:/ /inkscape.org (accessed on 1 February 2021).

46. Kondracki, J.; Richling, A. Regiony fizycznogeograficzne [in:] Atlas Rzeczpospolitej Polskiej; Główny Geodeta Kraju: Warsaw, Poland, 1994.

47. CBS i PBW Hydroprojekt. Kaskada Dolnej Wisty. Koncepcja 1957 [The Lower Vistula Cascade. The 1957 Concept]; CBS i PBW Hydroprojekt: Warsaw, Poland, 1957.

48. Szydlowski, M.; Szymkiewicz, R.; Gasiorowski, D.; Hakiel, J.; Zima, P. Hydraulic potential of the Lower Vistula (Poland). E3S Web Conf. 2018, 40, 3011. [CrossRef]

49. Kucharska, M.; Szwarc, P.K. Detailed Geological Map of Poland 1:50 000; Sheet 451 Wyszków; The Polish Geological InstituteNational Research Institute: Warsaw, Poland, 2012. Available online: http:/ / bazadata.pgi.gov.pl/data/smgp/arkusze_skany/ smgp0451.jpg (accessed on 1 February 2021).

50. Nitrychoruk, J.; Dzierżek, J.; Stańczuk, D. Detailed Geological Map of Poland 1:50 000; Sheet 532 Janów Podlaski; The Polish Geological Institute: Warsaw, Poland, 2003. Available online: http://bazadata.pgi.gov.pl/data/smgp/arkusze_skany/smgp0532.jpg (accessed on 1 February 2021).

51. Solon, J.; Borzyszkowski, J.; Bidłasik, M.; Richling, A.; Badora, K.; Balon, J.; Wójcik, B.T.; Chabudziński, Ł.; Dobrowolski, R.; Grzegorczyk, I.; et al. Physico-geographical mesoregions of Poland: Verification and adjustment of boundaries on the basis of contemporary spatial data. Geogr. Pol. 2018, 91, 143-170. [CrossRef]

52. Bałuk, A.; Petelski, K. Detailed Geological Map of Poland 1:50 000; Sheet 296 Łomża; The Polish Geological Institute-National Research Institute: Warsaw, Poland, 2009. Available online: http://bazadata.pgi.gov.pl/data/smgp/arkusze_skany/smgp0296.jpg (accessed on 1 February 2021).

53. Bałuk, A. Description to Detailed Geological Map of Poland 1:50 000; Sheet 333 Ostrołeka; The Polish Geological Institute: Warsaw, Poland, 1993. Available online: http:/ / bazadata.pgi.gov.pl/data/smgp/arkusze_txt/smgp0333.pdf (accessed on 1 February 2021).

54. Kmieciak, M. Detailed Geological Map of Poland 1:50 000; Sheet 379 Plutycze; The Polish Geological Institute: Warsaw, Poland, 2003. Available online: http:/ / bazadata.pgi.gov.pl/data/smgp/arkusze_skany/smgp0379.jpg (accessed on 1 February 2021).

55. Chachaj, J. Detailed Geological Map of Poland 1:50 000; Sheet 537 Czerwieńsk; The Polish Geological Institute: Warsaw, Poland, 2000. Available online: http:/ / bazadata.pgi.gov.pl/data/smgp/arkusze_skany/smgp0537.jpg (accessed on 1 February 2021).

56. Nowak, J. Detailed Geological Map of Poland 1:50 000; Sheet 538 Sulechów; The Polish Geological Institute: Warsaw, Poland, 2000. Available online: http:/ / bazadata.pgi.gov.pl/data/smgp/arkusze_skany/smgp0538.jpg (accessed on 1 February 2021).

57. Michalska, E. Detailed Geological Map of Poland 1:50 000; Sheet 688 Ścinawa; The Geological Institute, Poland: Warsaw, Poland, 1979. Available online: http:/ / bazadata.pgi.gov.pl/data/smgp/arkusze_skany/smgp0688.jpg (accessed on 1 February 2021). 
58. Michalska, E. Detailed Geological Map of Poland 1:50 000; Sheet 802 Otawa; The Polish Geological Institute: Warsaw, Poland, 1992. Available online: http://bazadata.pgi.gov.pl/data/smgp/arkusze_skany/smgp0802.jpg (accessed on 1 February 2021).

59. Szałamacha, G. Detailed Geological Map of Poland 1:50 000; Sheet 514 Koto; The Polish Geological Institute-National Research Institute: Warsaw, Poland, 1997. Available online: http://bazadata.pgi.gov.pl/data/smgp/arkusze_skany/smgp0514.jpg (accessed on 1 February 2021).

60. Klatkowa, H.; Załoba, M. Detailed Geological Map of Poland 1:50 000; Sheet 624 Warta; The Polish Geological Institute: Warsaw, Poland, 1990. Available online: http:/ / bazadata.pgi.gov.pl/data/smgp/arkusze_skany/smgp0624.jpg (accessed on 1 February 2021).

61. Ziomek, J.; Gałązka, D. Detailed Geological Map of Poland 1:50 000; Sheet 734 Osjaków; The Polish Geological Institute-National Research Institute: Warsaw, Poland, 2013. Available online: http://bazadata.pgi.gov.pl/data/smgp/arkusze_skany/smgp0734. jpg (accessed on 1 February 2021).

62. Kozłowska, M.; Kozłowski, I. Detailed Geological Map of Poland 1:50 000; Sheet 169 Kwidzyn; The Geological Institute: Warsaw, Poland, 1981. Available online: http:/ / bazadata.pgi.gov.pl/data/smgp/arkusze_skany/smgp0169.jpg (accessed on 1 February 2021).

63. Łyczewska, J. Detailed Geological Map of Poland 1:50 000; Sheet 362 Ciechocinek; The Geological Institute, Poland: Warsaw, Poland, 1973. Available online: http:// bazadata.pgi.gov.pl/data/smgp/arkusze_skany/smgp0362.jpg (accessed on 1 February 2021).

64. Skompski, S.; Słowiański, W. Detailed Geological Map of Poland 1:50 000; Sheet 444 Płock; The Geological Institute: Warsaw, Poland, 1962. Available online: http:/ / bazadata.pgi.gov.pl/data/smgp/arkusze_skany/smgp0444.jpg (accessed on 1 February 2021).

65. Makowska, A.; Skompski, S. Detailed Geological Map of Poland 1:50 000; Sheet 483 Stubice; The Geological Institute: Warsaw, Poland, 1962. Available online: http:/ / bazadata.pgi.gov.pl/data/smgp/arkusze_skany/smgp0483.jpg (accessed on 1 February 2021).

66. Makowska, A.; Ruszczyńska, H.; Kucharska, M.; Wasiluk, R. Detailed Geological Map of Poland 1:50 000; Sheet 484 Wyszogród; The Polish Geological Institute-National Research Institute: Warsaw, Poland, 2005. Available online: http://bazadata.pgi.gov.pl/ data/smgp/arkusze_skany/smgp0484.jpg (accessed on 1 February 2021).

67. Nowak, J.; Skompski, S. Detailed Geological Map of Poland 1:50 000; Sheet 486 Modlin-Twierdza; The Polish Geological Institute: Warsaw, Poland, 1992. Available online: http:/ / bazadata.pgi.gov.pl/data/smgp/arkusze_skany/smgp0486.jpg (accessed on 1 February 2021).

68. Sarnacka, Z. Detailed Geological Map of Poland 1:50 000; Sheet 524 Warszawa Wschód; The Geological Institute: Warsaw, Poland, 1979. Available online: http:/ / bazadata.pgi.gov.pl/data/smgp/arkusze_skany/smgp0524.jpg (accessed on 1 February 2021).

69. Dowgiałło, W.D. Detailed Geological Map of Poland 1:50 000; Sheet 746 Kazimierz Dolny; The Geological Institute: Warsaw, Poland, 1981. Available online: http:/ / bazadata.pgi.gov.pl/data/smgp/arkusze_skany/smgp0746.jpg (accessed on 1 February 2021).

70. Wierzbicki, G.; Grygoruk, M.; Grodzka-Łukaszewska, M.; Bartold, P.; Okruszko, T. Mire Development and Disappearance due to River Capture as Hydrogeological and Geomorphological Consequences of LGM Ice-Marginal Valley Evolution at the Vistula-Neman Watershed. Geosciences 2020, 10, 363. [CrossRef]

71. Hauer, C.; Pulg, U. The non-fluvial nature of Western Norwegian rivers and the implications for channel patterns and sediment composition. CATENA 2018, 171, 83-98. [CrossRef]

72. Hauer, C.; Pulg, U. Buried and forgotten-The non-fluvial characteristics of postglacial rivers. River Res. Appl. 2020, rra.3596. [CrossRef]

73. Geiger, H. Instream River Training-Stream Design in Oehringen according to Viktor Schauberger's Principles. Wasserwirtschaft 2013, 103, 47-48. [CrossRef]

74. Werdenberg, N.; Mende, M.; Sindelar, C. Instream river training: Fundamentals and practical example. In River Flow 2014; CRC Press: Boca Raton, FL, USA, 2014; pp. 1571-1577.

75. Bagnold, R.A. An Approach to the Sediment Transport Problem from General Physics; US Government Printing Office: Washington, DC, USA, 1966.

76. Vayssière, A.; Castanet, C.; Gautier, E.; Virmoux, C.; Dépret, T.; Gandouin, E.; Develle, A.L.; Mokadem, F.; Copard, S.S.; Sabatier, P.; et al. Readjustments of a sinuous river during the last 6000 years in northwestern Europe (Cher River, France): From an active meandering river to a stable river course under human forcing. Geomorphology 2020, 370, 7395. [CrossRef]

77. Venditti, J.G.; Li, T.; Deal, E.; Dingle, E.; Church, M. Struggles with stream power: Connecting theory across scales. Geomorphology 2020, 366, 6817. [CrossRef]

78. Bull, W.B. Threshold of critical power in streams. Geol. Soc. Am. Bull. 1979, 90, 453-464. [CrossRef]

79. Nanson, G.C.; Croke, J.C. A genetic classification of floodplains. Geomorphology 1992, 4, 459-486. [CrossRef]

80. Wierzbicki, G.; Ostrowski, P.; Mazgajski, M.; Bujakowski, F. Using VHR multispectral remote sensing and LIDAR data to determine the geomorphological effects of overbank flow on a floodplain (the Vistula River, Poland). Geomorphology 2013, 183, 73-81. [CrossRef]

81. Betz, F.; Lauermann, M.; Cyffka, B. Open Source Riverscapes: Analyzing the Corridor of the Naryn River in Kyrgyzstan Based on Open Access Data. Remote Sens. 2020, 12, 2533. [CrossRef]

82. Hrabia, B.A.; Strugała, K.M.; Bryndal, T.; Cebulski, J.; Kiszka, K.; Kroczak, R. An integrated approach for investigating geomorphic changes due to flash flooding in two small stream channels (Western Polish Carpathians). J. Hydrol. Reg. Stud. 2020, 31, 731. [CrossRef] 
83. Candel, J.; Kleinhans, M.; Makaske, B.; Wallinga, J. Predicting river channel pattern based on stream power, bed material and bank strength. Prog. Phys. Geogr. Earth Environ. 2020. [CrossRef]

84. Gu, Z.; Fan, H.; Yang, K. GIS and DEM based analysis of incision and drainage reorganization of the Buyuan River basin in the upper Lancang-Mekong of China since the Late Pleistocene. J. Geogr. Sci. 2020, 30, 1495-1506. [CrossRef]

85. Tranmer, A.W.; Caamaño, D.; Goodwin, P. Identifying dynamic equilibrium of an undeveloped alluvial stream by extremal hypotheses. CATENA 2020, 194, 4680. [CrossRef]

86. Tullis, B.; Bradshaw, R. Impact Dissipators; Chanson, H., Ed.; CRC press: Boca Raton, FL, USA, 2015; pp. $131-157$.

87. Roman, M. Ice-flow directions of the last Scandinavian Ice Sheet in central Poland. Quat. Int. 2019, 501, 4-20. [CrossRef]

88. Brykczyński, M. Valley-side glaciotectonics in the Warsaw Basin and Płock Basin. Pr. Muz. Ziemi 1982, 35, 3-68.

89. Narloch, W.; Phillips, E.R.; Piotrowski, J.A.; Ćwiek, M. Patterns of deformation within a subglacial shear zone: Implications for palaeo-ice stream bed evolution. Sediment. Geol. 2020, 397, 5569. [CrossRef]

90. Vestøl, O.; Ågren, J.; Steffen, H.; Kierulf, H.; Tarasov, L. NKG2016LU: A new land uplift model for Fennoscandia and the Baltic Region. J. Geod. 2019, 93, 1759-1779. [CrossRef]

91. Skompski, S. Stratygrafia osadów czwartorzędowych wschodniej części Kotliny Płockiej. Biul. Inst. Geol. 1969, 220, 175-258.

92. Wierzbicki, G. Geological Setting Controls on a Floodplain Morphodynamics in the Vistula River Valley near Kepa Polska. Ph.D. Thesis, Warsaw University of Life Sciences SGGW-WULS, Warszawa, Poland, 2015.

93. Wysota, W.; Molewski, P.; Sokołowski, R.J. Record of the Vistula ice lobe advances in the Late Weichselian glacial sequence in north-central Poland. Quat. Int. 2009, 207, 26-41. [CrossRef]

94. Fuller, I.C.; Gilvear, D.J.; Thoms, M.C.; Death, R.G. Framing resilience for river geomorphology: Reinventing the wheel? River Res. Appl. 2019, 35, 91-106. [CrossRef]

95. Coltorti, M.; Dramis, F.; Ollier, C.D. Planation surfaces in Northern Ethiopia. Geomorphology 2007, 89, 287-296. [CrossRef] 